\title{
Faktor-Faktor Yang Mempengaruhi Ketahanan Pangan Rumah Tangga Petani Di Kabupaten Klaten
}

\author{
Wahyu Adhi Saputro ${ }^{*}$ \\ Yuli Fidayani ${ }^{2}$ \\ 1),2) Program Studi Agribisnis, Fakultas Sains dan Teknologi, Universitas Duta Bangsa Surakarta \\ *e-mail: wahyuadhi@udb.ac.id \\ Diterima: Juli 2020, Disetujui:September 2020, Dipublish: Oktober 2020
}

\begin{abstract}
Abstrak
Pangan merupakan kebutuhan dasar dari manusia selain sandang dan papan. Pangan dibutuhkan sebagai upaya kelangsungan hidup manusia. Terpenuhinya kebutuhan pangan dari berbagai segi seperti keamanan, keterjangkauan dan aspek lain sering dikaitkan dengan ketahanan pangan. Tujuan dari penelitian ini untuk mengetahui faktor-faktor apa saja yang mempengaruhi ketahanan pangan. Populasi dari penelitian ini adalah seluruh rumah tangga petani yang ada di Kabupaten Klaten dan sampel dari penelitian ini adalah petani yang tergabung dalam desa mandiri pangan di Kabupaten Klaten. Responden pada peneitian ini berjumlah 30 orang petani yang berasal dari desa dengan program mandiri pangan serta desa yang memiliki klinik pertanian yaitu Desa Jambakan dan Desa Karanglo. Penelitian ini menggunakan metode analisis regresi linear berganda. Analisis ketahanan pangan dalam penelitian ini menggunakan pendekatan pangsa pengeluaran pangan. Berdasarkan hasil penelitian dapat diketahui ada tiga variabel yang mempengaruhi ketahanan pangan diantaranya adalah tingkat pendapatan, harga beras dan dummy pengetahuan gizi oleh ibu rumah tangga. Terdapat pula empat variabel yang tidak mempengaruhi ketahanan pangan diantaranya adalah jumlah tanggungan keluarga, pendidikan ibu rumah tangga, harga minyak dan harga tempe.
\end{abstract}

Kata kunci: pangan, ketahanan pangan, pengeluaran pangan

\begin{abstract}
Food is a basic human need besides clothing and shelter. Food is needed as an effort for human survival. Fulfilling food needs from various aspects such as security, affordability and other aspects is often associated with food security. The purpose of this study was to determine what factors affect food security. The population of this study were all farmer households in Klaten Regency and the sample of this study were farmers who are members of the independent food village in Klaten Regency. Respondents in this study were 30 farmers who came from villages with independent food programs and villages that had agricultural clinics, namely Jambakan Village and Karanglo Village. This research uses multiple linear regression analysis method. Food security analysis in this study uses a share offood expenditure approach. Based on the research results, it can be seen that there are three variables that affect food security, including the level of income, rice price and dummy nutrition knowledge by housewives. There are also four variables that do not affect food security, including the number of family dependents, the education of housewives, the price of oil and the price of tempe.
\end{abstract}

Keywords: food, food security, food expenditure

\section{PENDAHULUAN}

Kebutuhan dasar manusia salah satunya dicukupi dari aspek pangan. Pangan mengandung zat gizi yang digunakan untuk mempertahankan kelangsungan hidup. Pangan juga memiliki fungsi sebagai upaya pemulihan dan perbaikan jaringan tubuh yang rusak. Fungsi lain dari pangan untuk mengatur proses di dalam tubuh, 
perkembangbiakan dan menjalankan aktivitas dalam kehidupan (Nasmiati, Ginting, \& Rahman, 2014). Setiap orang berhak memperoleh makanan yang cukup dan layak disesuaikan dengan kebutuhannya disamping itu ketahanan pangan adalah hak asasi manusia (HAM) (Damayanti \& Khoirudin, 2016). Ketahanan pangan merupakan terpenuhinya pangan bagi rumah tangga yang cukup baik dari segi jumlah, mutu, keamanan pangan, merata dan terjangkau (Badan Ketahanan Pangan Kementan RI, 2013). Salah satu indikator yang menjadikan ketahanan pangan bagi rumah tangga tani yaitu pangsa pengeluaran pangan. Ratio antara pengeluaran pangan dengan pengeluaran total rumah tangga perbulan merupakan perhitungan dari pangsa pengeluaran pangan (Mulyo, Sugiyarto, \& Widada, 2016).

Permasalahan mengenai ketahanan pangan adalah masalah dasar dan harus ditangani secara berkelanjutan. Peningkatan penduduk setiap tahunnya mempengaruhi ketahanan pangan. Hal tersebut juga dikarenakan kapasitas produksi pangan yang berada pada levelling off. Kondisi demikian disebabkan pemanfaatan lahan intensif dan berdampak pada kesuburan lahan yang menurun. Dorongan adanya alih fungsi lahan menjadi lahan non pertanian diduga berperan terhadap ketersediaan pangan masyarakat (Nurdiani \& Widjojoko, 2016). Penurunan produksi pertanian disebabkan juga oleh pengaruh iklim (Hapsari \& Rudiarto, 2017). Jika membandingkan skala rumah tangga yang tidak tahan pangan dikarenakan faktor kemiskinan. Rendahnya kepedulian masyarakat setempat ditambah dengan tidak ada kelembagaan ketahanan pangan ditingkat masyarakat menyebabkan adanya tidak tahan pangan di tingkat rumah tangga tani (Sumardilah \& Rahmadi, 2015). Desa yang masih terdapat masalah ketahanan pangan belum dikatakan mandiri. Hal tersebut tercermin dari tidak adanya peningkatan kesejahteraan dan pendapatan masyarakatnya. Terdapat beberapa upaya pemerintah dalam menyelesaikan hal tersebut salah satu antisipasi yang dilakukan dengan mengadakan program Desa Mandiri Pangan dengan tujuan aksi dalam pengurangan kondisi rawan pangan di pedesaan (Agustina Arida, Sofyan, 2015). Namun perlu penyelesaian secara lebih serius dan berkelanjutan dalam hal ketahanan pangan baik dalam skala kapita maupun nasional.

Omotesho et al (2010) melakukan penelitian tentang Ketahanan Pangan dan Kemiskinan dari Rumah tangga pedesaan di Kwara State, Nigeria. Hasil penelitian mengungkapkan bahwa 66\% sampel rumah tangga jatuh di bawah garis kemiskinan dan oleh karena itu bisa dikatakan miskin. Pendapatan nonpertanian merupakan penentu utama dari probabilitas sebuah rumah tangga yang tidak miskin. Rumah tangga yang memiliki sumber-sumbernon-pertanian pendapatan cenderung mudah keluar dari kemiskinan daripada rumah tangga yang tidak memiliki sumber penghasilan lain di luar pertanian. 
Rerata total kecukupan kalori (kkal) Kabupaten Klaten pada tahun 2016 sebesar 1.951 kkal. Kecukupan kalori terbesar adalah beras sebanyak 788,28 kkal atau sebesar 40,39\% (Astanto, 2016). Tingkat konsumsi pangan tersebut juga masih menunjukkan dominasi dari konsumsi padi-padian terutama beras kemudian diikuti konsumsi panga hewani dan kacangkacangan. Data yang ada mengungkapkan bahwa wilayah Kabupaten Klaten masih memiliki nilai terendah terhadap asupan kalori dan konsumsi energi. Jika ditinjau dari nilai reratanya AKE di Kabupaten Klaten sudah cukup mendekati batas minimum namun hal tersebut bukan gambaran keadaan konsumsi pangan di tingkat rumah tangga khususnya rumah tangga tani (Amaliyah, H. , Mulya, 2011). Kabupaten Klaten merupakan salah satu daerah penyangga dengan luas panen padi sawah seluas $65.629 \mathrm{Ha}$, dengan produksi sebanyak 359,474 ton pada tahun 2014. Kabupaten Klaten memiliki lahan pertanian untuk penggunaan lahan sawah 33.220 Ha atau sekitar 50,6\% dari total luas wilayah Kabupaten Klaten (BPS, 2014). Berdasarkan uraian tersebut maka penelitian ini bertujuan untuk mengetahui faktor-faktor apa saja yang mempengaruhi ketahanan pangan di Kabupaten Klaten.

\section{METODE PENELITIAN}

Penelitian yang dilakukan merupakan rancangan penelitian cross sectional. Hal ini dikarenakan dalam mengukur variabel independen dan variabel dependen dilakukan dalam waktu yang sama. Pemilihan rancangan tersebut dikarenakan lebih cepat dan sederhana dan bisa menjawab tujuan penelitian. Penelitian ini merupakan penelitian dengan metode deskriptif analitik. Populasi dalam penelitian ini adalah semua petani yang ada di Kabupaten Klaten. Sementara itu sampel dalam penelitian ini adalah petani pada desa yang mengikuti program desa mandiri pangan. Data yang digunakan dalam penelitian ini meliputi data primer dan data sekunder. Data primer merupakan data yang dikumpulkan secara langsung dari hasil wawancara kepada petani menggunakan kuesioner yang telah disusun sedemikian rupa. Responden yang digunakan dalam penelitian ini berjumlah 30 orang yang berasal dari desa mandiri pangan dan desa yang memiliki klinik pertanian yaitu Desa Jambakan dan Desa Karanglo. Data sekunder merupakan data yang berasal dari dinas terkait serta jurnal-jurnal dan buku yang relevan.

Pangsa pengeluaran pangan ialah persentase pengeluaran pangan rumah tangga terhadap pengeluaran total rumah tangga. Cara menghitung pangsa pengeluaran pangan rumah tangga, digunakan persamaan sebagai berikut (Mulyo et al., 2016):

$$
\mathrm{PPP}=\mathrm{PP} / \mathrm{TP} \times 100 \%
$$

Keterangan :

PPP : Pangsa Pengeluaran Pangan (\%)

PP : Pengeluaran Pangan Rumah Tangga (Rp/tahun)

TP : Total Pengeluaran Rumah Tangga (Rp/tahun).

Persentase yang dihasilkan dari perhitungan tersebut kemudian dapat 
dikategorikan dengan ketentuan sebagai berikut :

a. Pangsa Pengeluaran Pangan $<60 \%$ dari total pengeluaran merupakan rumah tangga tahan pangan.

b. Pangsa Pengeluaran Pangan $\geq 60 \%$ dari total pengeluaran merupakan rumah tangga tidak tahan pangan.

Penelitian ini menggunakan variabel dependen yaitu pangsa pengeluaran pangan. Perhitungan mengenai pangsa pengeluaran pangan dapat dicari dengan membagi pengeluaran pangan terhadap pengeluaran total rumah tangga petani. Hasil dari pangsa pengeluaran tersebut dapat dijadikan sebagai acuan dari tingkat ketahanan pangan rumah tangga. Tingkat ketahanan pangan rumah tangga petani dapat diukur tidak hanya menggunakan pangsa pengeluaran pangan saja namun bisa juga menggunakan indikator silang antara pangsa pengeluaran pangan dan kecukupan energi rumah tangga tani (Putri, Murniati, \& Adawiyah, 2019). Namun hal tersebut tidak dilakukan dalam penelitian ini karena keterbatasan penelitian. Berikut ini adalah model regresi yang dilakukan dalam penelitian ini:

$$
\begin{aligned}
\mathrm{Y}= & \alpha 0+\beta_{1} \mathrm{X}_{1}+\beta_{2} \mathrm{X}_{2}+\beta_{3} \mathrm{X}_{3}+\beta_{4} \mathrm{X}_{4}+\beta_{5} \mathrm{X}_{5}+\beta_{6} \\
& \left.\mathrm{X}_{6}+\beta_{7} \mathrm{X}_{7}+\mathrm{e} \ldots \ldots \ldots . .2\right)
\end{aligned}
$$

Keterangan :

$$
\begin{array}{lll}
\mathrm{Y} & = & \text { Pangsa pengeluaran pangan } \\
& \text { rumah tangga petani }(\%) \\
\alpha 0 & = & \text { Intersept } \\
\beta 1-\beta 7= & \text { koefisien regresi } \\
& \text { (parameter yang ditaksir) } \\
\mathrm{e} & =\text { error term (residual) } \\
\mathrm{X}_{1}= & \text { Jumlah tanggungan } \\
& \text { keluarga (orang) }
\end{array}
$$

$$
\begin{aligned}
\mathrm{X}_{2}= & \text { Tingkat pendapatan } \\
& (\mathrm{Rp} / \text { bulan) } \\
\mathrm{X}_{3}= & \text { Pendidikan ibu rumah } \\
& \text { tangga (tahun) } \\
\mathrm{X}_{4}= & \text { Harga beras (Rp/kg) } \\
\mathrm{X}_{5}= & \text { Harga minyak (Rp/L) } \\
\mathrm{X}_{6}= & \text { Harga tempe (Rp/bungkus) } \\
\mathrm{X}_{7}= & \text { Dummy pengetahuan gizi } \\
& \text { oleh ibu rumah tangga } \\
& 1=\text { Tahu mengenai gizi } \\
& \text { makanan } \\
& 0=\text { Tidak tahu mengenai gizi } \\
& \text { makanan }
\end{aligned}
$$

\section{HASIL DAN PEMBAHASAN}

\section{Pangsa Pengeluaran Pangan Rumah Tangga Petani}

Pengeluaran pangan dan non pangan merupakan pengeluaran masyarakat secara umum. Analisis kesejahteraan masyarakat sebenarnya bisa dilihat dari variabel pengeluaran pangan yang dibagi dengan pengeluaran total. Persentase mengenai pengeluaran pangan rumah tangga petani dibagi dengan pengeluaran total rumah tangga identic dengan pangsa pengeluaran pangan. Rendahnya pangsa pengeluaran pangan berarti semakin membaik kesejahteraan masyarakat. Hal ini diasumsikan karena masyarakat sudah bisa membeli pengeluaran lain selain pangan dengan artian non pangan lebih besar dari pengeluaran pangannya. Terdapat hubungan terbalik antara pangsa pengeluaran pangan dengan ketahanan pangan. Menurunnya pangsa pengeluaran pangan justru ketahanan pangan meningkat begitu juga sebaliknya. Perhitungan mengenai pangsa pengeluaran pangan rumah tangga petani yang ada di Kabupaten 
Klaten dapat dijabarkan dengan perhitungan matematis sebagai berikut:

$$
\mathrm{PPP}=\frac{11.277 .075}{20.869 .275} \times 100 \%=54,03 \%
$$

Rumah tangga dapat dikatakan tahan pangan jika nilai pangsa pengeluaran pangannya (PPP) kurang dari $60 \%$ namun jika nilai pangsa pengeluaran pangannya lebih dari $60 \%$ maka rumah tangga dikatakan tidak tahan pangan. Jika dilihat dari perhitungan maka dapat diketahui rerata pangsa pengeluaran pangan di Kabupaten Klaten adalah 54,03\%. Nilai tersebut menunjukkan bahwa persentase tersebut lebih kecil dari $60 \%$ sehingga dapat dikategorikan bahwa rumah tangga petani di Kabupaten Klaten berada pada kategori tahan pangan. Distribusi rumah tangga tani berdasarkan pangsa pengeluaran pangan dapat dilihat pada tabel 1 .

Tabel 1. Distribusi Pangsa Pengeluaran Pangan (PPP) Rumah Tangga Tani di Kabupaten Klaten Tahun 2020.

\begin{tabular}{ccc}
\hline Pangsa Pengeluaran Pangan & \multicolumn{2}{c}{ Rumah Tangga Tani } \\
& Jumlah & Persentase (\%) \\
\hline$>$ Rerata $(54,03 \%)$ & 12 & 40 \\
SRerata $(54,03 \%)$ & 18 & 60 \\
\hline Jumlah & $\mathbf{3 0}$ & $\mathbf{1 0 0}$ \\
\hline
\end{tabular}

Sumber : Analisis Data Primer (2020)

Berdasarkan tabel 1 dapat diketahui terdapat $18(60 \%)$ rumah tangga petani di Kabupaten klaten yang memiliki nilai pangsa pengeluaran pangan di bawah rerata sedangkan sisanya sebanyak 12 rumah tangga petani atau sebesar $40 \%$ memiliki nilai pangsa pengeluaran pangan di atas nilai rerata. Hal itu menununjukkan bahwa sebenarnya sebagian besar rumah tangga petani memiliki pangsa pengeluaran yang rendah dan kurang dari 60\%. Rumah tangga petani dengan nilai pangsa pengeluaran pangan besar maka identik dengan nilai ketahanan pangan rumah tangga yang rendah. Pengeluaran antara pangan dan non pangan milik rumah tangga petani harusnya lebih besar pengeluaran non pangan sehingga nilai pangsa pangannya akan membaik. Hal tersebut senada dengan penelitian
Susanti (2015) yang menyatakan bahwa masih terdapat rumah tangga yang memiliki pangsa pengeluaran pangan yang besar dikarenakan rumah tangga tersebut kebutuhan pangannya lebih besar dari pada pengeluaran lainnya.

\section{Faktor-Faktor Yang Mempengaruhi Ketahanan Pangan}

Data yang sudah lolos dari uji normalitas dan uji asumsi klasi maka dapat dilanjutkan dengan analisis regresi linear sederhana. Analisis ini digunakan untuk mengukur dan mengetahui pengaruh dari variabel independen apa saja terhadap variabel dependennya. Dalam regresi linear berganda maka digunakan variabel independen lebih dari satu. Hasil analisis faktor-faktor yang mempengaruhi ketahanan pangan tingkat rumah tangga tani dapat dilihat pada tabel 2 berikut ini. 
Tabel 2. Hasil Analisis Linier Berganda Faktor-faktor yang Mempengaruhi Ketahanan Pangan Tingkat Rumah Tangga Tani di Kabupaten Klaten

\begin{tabular}{|c|c|c|c|}
\hline Var. & Koefisien & t-hit & Sig. \\
\hline $\mathrm{C}$ & -13.8792 & -1.4086 & 0.1649 \\
\hline $\mathrm{X}_{1}$ & $0.0012 \mathrm{~ns}$ & 1.7205 & 0.0913 \\
\hline $\mathrm{X}_{2}$ & $-1.4906^{*}$ & -2.4285 & 0.0187 \\
\hline $\mathrm{X}_{3}$ & $0.008^{\mathrm{ns}}$ & 0.1904 & 0.8497 \\
\hline $\mathrm{X}_{4}$ & $0.0253^{*}$ & 2.1054 & 0.0401 \\
\hline $\mathrm{X}_{5}$ & $0.3805^{n s}$ & 0.9787 & 0.3322 \\
\hline $\mathrm{X}_{6}$ & $-1.8605^{n s}$ & -0.8038 & 0.9362 \\
\hline$X_{7}$ & $2.5968^{*}$ & 3.1478 & 0.0027 \\
\hline \multicolumn{3}{|c|}{ Adjusted $\mathrm{R}^{2}$} & 0.4837 \\
\hline \multicolumn{3}{|c|}{ F hitung } & 2.4684 \\
\hline \multicolumn{3}{|c|}{ F sig. } & 0.0289 \\
\hline
\end{tabular}

Tabel 2 menunjukan hasil analisis regresi linear berganda faktor-faktor yang mempengaruhi ketahanan pangan. Variabel dependen yang digunakan dalam penelitian ini adalah pangsa pengeluaran pangan. Variabel independen merupakan variabel yang diduga merupakan faktor yang berpengaruh terhadap pangsa pengeluaran pangan seperti jumlah tanggungan keluarga, tingkat pendapatan, pendidikan ibu, harga beras, harga minyak, harga tempe dan dummy variabel pengetahuan gizi. Pangsa pengeluaran pangan memiliki hubungan yang berlawanan dengan ketahanan pangan. Artinya semakin menurun pangsa pengeluaran pangan menunjukan ketahanan pangan yang semakin meningkat, begitu juga sebaliknya. Persamaan regresi linear berganda faktorfaktor yang mempengaruhi ketahanan pangan rumah tangga petani di Kabupaten Klaten sebagai berikut :

$$
\begin{aligned}
Y= & -13,8792+0,0012 X 1-1,4906 X 2+0,008 X 3 \\
& +0,0253 X 4+0,3805 X 5-1,8605 X 6+ \\
& 2,5986 X 7+\mu
\end{aligned}
$$

\section{Koefisien Determinasi}

Nilai adjusted $R^{2}$ memiliki range nilai dimulai dari angka 0 hingga 1 . Apabila hasil tersebut dekat dengan angka 1 maka model dapat dikatakan semakin baik. Nilai adjusted $R^{2}$ dapat dilihat pada tabel 3 dengan nilai sebesar 0,4837 atau $48,37 \%$. Dengan demikian dapat disimpulkan bahwa 48,37 persen dari variasi variabel dependen dapat dijelaskan oleh variabel independennya. Dalam penelitian ini variabel dependennya yaitu pangsa pengeluaran pangan dan variabel indepedennya ada tujuh variabel meliputi jumlah tanggungan keluarga, tingkat pendapatan, pendidikan ibu, harga beras, harga minyak, harga tempe dan dummy variabel pengetahuan gizi. Sisa dari nilai adjusted $R^{2}$ sebesar 51,63 persen dijelaskan oleh variabel lain di luar model yang diteliti.

\section{Uji-F}

Setelah dilakukan uji koefisien determinasi maka uji lanjutan yang akan dilakukan adalah uji-F. Pengujian ini diperuntukkan melihat pengaruh variabel independen secara simultan terhadap variabel dependennya. Uji-F dapat dilihat pada tabel 3 melalui nilai signifikansi $F$. nilai signifikansi $F$ menunjukkan nilai 0,0289 atau nilainya lebih kecil dari 0,05. Hal tersebut dapat diartikan bahwa variabel independen yaitu jumlah tanggungan keluarga, tingkat pendapatan, pendidikan ibu, harga beras, harga minyak, harga tempe dan dummy variabel pengetahuan gizi secara simultan/ bersama-sama 
mempengaruhi pangsa pengeluaran pangan.

\section{Uji-t}

Berdasarkan tabel 3 variabel pendapatan memiliki nilai signifikansi sebesar 0,01 lebih kecil dari $\alpha=5 \%$, sehingga pendapatan secara individu berpengaruh terhadap pangsa pengeluaran pangan pada tingkat kepercayaan 95\%. Hal tersebut sesuai dengan penelitian yang dilakukan oleh Sianipar et al, (2012) bahwa pendapatan berpengaruh terhadap ketahanan pangan. Jika melihat dari nilai koefisien regresi dari variabel pendapatan sebesar -1,49 maka dapat dikatakan bahwa kenaikan pendapatan sebesar 1 satuan maka akan menurunkan nilai pangsa pengeluaran pangan sebesar 1,49 satuan. Hal tersebut dikarenakan seorang yang memiliki pendapatan tinggi biasanya mengalokasikan pengeluaran pangannya relatif tetap dan justru memperbaiki kualitas makan serta mengalokasikan dana yang lebih ke sektor non pangan. Dengan demikian dapat dikatakan bahwa ada perbandingan terbalik antara pangsa pengeluaran pangan dengan tingkat pendapatan.

Variabel harga beras memiliki nilai signifikansi sebesar 0,04 lebih kecil dari $\alpha$ $=5 \%$, sehingga harga beras secara individu berpengaruh terhadap pangsa pengeluaran pangan pada tingkat kepercayaan 95\%. Jika melihat dari nilai koefisien regresi dari variabel harga beras sebesar 0,02 maka dapat dikatakan bahwa kenaikan harga beras sebesar 1 satuan maka akan menaikkan nilai pangsa pengeluaran pangan sebesar 0,02 satuan. Semakin tinggi harga dari bahan pangan pokok maka akan berpengaruh terhadap pengeluaran pangan rumah tangga. Hal ini sesuai dengan penelitian Mukhson dkk (2017) yang menyatakan bahwa harga bahan pangan pokok seperti beras yang baik maka akan menaikan pangsa pengeluaran pangan dengan begitu dapat dikatakan bahwa tingginya harga bahan pokok akan mempengaruhi tingginya pengeluaran pangan yang akan mempengaruhi juga tingkat ketahanan pangan. Hal tersebut juga didasari bahwa sebagian besar masyarakat masih mengandalkan beras sebagai makanan pokok/utama. Dengan begitu petani akan mengeluarkan uang yang lebih jika harga beras naik. Harga beras setiap waktu ke waktu terus mengalami perubahan dan terdapat kenaikan harga disetiap tahunnya padahal harga beras adalah instrument penting dalam stabilitas pasokan beras yang berujung pada peningkatan ketahanan pangan (Suryana, Rachman, \& Hartono, 2014).

Berdasarkan tabel 3 dapat diketahui bahwa nilai signifikansi dari variabel dummy pengetahuan gizi ibu rumah tangga adalah 0,0027 sehingga nilai tersebut kurang dari 0,05. Nilai tersebut mengindikasikan adanya pengaruh variabel dummy pengetahuan gizi ibu rumah tangga terhadap pangsa pengeluaran pangan. Jika dilihat dari nilai koefisien regresi sebesar 2,5968 maka dapat dikatakan bahwa terdapat perbedaan pangsa pengeluaran antara rumah tangga yang memiliki ibu rumah tangga dengan pengetahuan gizi jika dibandingkan dengan keluarga yang ibu rumah tangganya tidak tahu mengenai gizi makanan. Hal ini senada dengan 
penelitian yang menyatakan bahwa ibu dengan pengetahun gizi yang baik akan lebih cermat dalam memilih makanan dengan pertimbangan nilai gizi dan kebutuhan gizi rumah tangga (Amaliyah, H. , Mulya, 2011). Kondisi demikian menyebabkan rumah tangga tersebut lebih sejahtera dengan pangsa pengeluaran pangan lebih teratur. Tingkat pola konsumsi pangan yang sudah baik perlu dijaga dan dipertahankan dengan mempertahankan pemenuhan gizi. Upaya tersebut bisa juga dilakukan dengan penyuluhan pada ibu-ibu PKK atau ibu petani di desa yang merupakan orang yang menyediakan pangan bagi anggota keluarganya dengan begitu ketahanan pangan pada rumah tangga petani dapat terjaga (Sugiarto, Ugih; Karyani, Tuti; Rochdiani, 2018).

Terdapat beberapa variabel independen yang tidak berpengaruh yaitu pendidikan ibu rumah tangga, harga minyak, dan harga tempe. Hal tersebut dikarenakan nilai signifikansi dari masing masing variabel independen tersebut bernilai lebih dari 0,05. Nilai signifikansi dari variabel pendiidkan ibu rumah tingga adalah 0,8497 sedangkan Nilai signifikansi dari variabel harga minyak adalah 0,3322 . Nilai signifikansi dari variabel harga tempe adalah 0,9362. Dengan demikian dapat dikatakan bahwa variabel pendidikan ibu rumah tangga, harga minyak, dan harga tempe tidak berpengaruh terhadap pangsa pengeluaran pangan.

\section{SIMPULAN}

Berdasarkan penelitian yang telah dilakukan didapatkan kesimpulan bahwa terdapat tiga variabel independen yang berpengaruh secara parsial terhadap variabel pangsa pengeluaran pangan. Variabel tersebut adalah variabel tingkat pendapatan, harga beras dan dummy pengetahuan gizi oleh ibu rumah tangga. Sementara itu terdapat empat variabel independen yang tidak berpengaruh secara parsial terhadap pangsa pengeluaran pangan. Keempat variabel tersebut adalah jumlah anggota keluarga, tingkat pendidikan ibu rumah tangga, harga minyak dan harga tempe. Sebaiknya rumah tangga petani dapat meningkatkan sisi pendapatan dari sektor usahatani maupun luar usahatani karena hal tersebut berdampak pada ketahana pangan rumah tangga tani. Sebaiknya petani juga melakukan variasi pangan yang beranekaragam. Hal tersebut dikarenakan agar petani tidak terlalu bergantung pada komsumsi satu jenis makanan pokok yaitu beras.

\section{UCAPAN TERIMAKASIH}

Ucapan terima kasih diberikan kepada Direktorat Riset dan Pengabdian Masyarakat, Deputi Bidang Penguatan Riset dan Pengembangan, Kementerian Riset, Teknologi, Badan Riset dan Inovasi Nasional Republik Indonesia yang telah memberikan dana penelitian dosen pemula. Tidak lupa Ucapan terima kasih juga diberikan kepada LPPM Universitas Duta Bangsa Surakarta yang telah memberikan izin penelitian.

\section{DAFTAR PUSTAKA}

Agustina Arida, Sofyan, K. F. (2015). Analisis Ketahanan Pangan Rumah Tangga Berdasarkan Proporsi Pengeluaran Pangan Dan Konsumsi Energi (Studi Kasus Pada Rumah Tangga Petani 
Peserta Program Desa Mandiri Pangan Di Kecamatan Indrapuri Kabupaten Aceh Besar). 16(1), 20-34. https://doi.org/10.24815/agrisep.v16i 1.3028

Amaliyah, H. , Mulya, S. . (2011). Analisis Hubungan Proporsi Pengeluaran dan Konsumsi Pangan Dengan Ketahanan Pangan Rumah Tangga Petani Padi di Kabupaten Klaten. SEPA, 7(2), 110-118.

Astanto, D. N. (2016). Ketahanan Pangan Rumah Tangga Petani Di Kecamatan Wedi Kabupaten Klaten. Universitas Gadjah Mada.

Badan Ketahanan Pangan Kementan RI. (2013). Petunjuk Pelaksanaan Sistem Kewaspadaan Pangan dan Gizi. Jakarta: BKP Kementan RI.

BPS. (2014). Statistik Kabupaten Klaten.

Damayanti, V. L., \& Khoirudin, R. (2016). Analisis Faktor - Faktor Yang Mempengaruhi Ketahanan Pangan Rumah Tangga Petani (Studi Kasus: Desa Timbulharjo, Sewon, Bantul). Jurnal Ekonomi \& Studi Pembangunan, 17(2).

https://doi.org/10.18196/jesp.17.2.37 35

Hapsari, N. I., \& Rudiarto, I. (2017). FaktorFaktor yang Mempengaruhi Kerawanan dan Ketahanan Pangan dan Implikasi Kebijakannya di Kabupaten Rembang. Jurnal Wilayah Dan Lingkungan, 5(2), 125.

https://doi.org/10.14710/jwl.5.2.125140

M. A. Rachmah, Mukson, S. M. (2017). Analisis Faktor-Faktor Yang Mempengaruhi Pangsa Pengeluaran Pangan Rumah Tangga Petani Di Kecamatan Suruh Kabupaten Semarang. Jurnal Unimus, 1(3), 17-27.

Mulyo, J. H., Sugiyarto, S., \& Widada, A. W. (2016). Ketahanan Dan Kemandirian Pangan Rumah Tangga Tani Daerah Marginal Di Kabupaten Bojonegoro. Agro Ekonomi, 26(2), 121. https://doi.org/10.22146/agroekonom i. 17265

Nasmiati, C., Ginting, R., \& Rahman, A. (2014). Analisis Produksi dan Ketersediaan Serta Kebutuhan Kedelai Dalam
Kaitannya Dengan Ketahanan Pangan di Provinsi Sumatera Utara. Jurnal Agribisnis Sumatera Utara, 7(1).

Nurdiani, U., \& Widjojoko, T. (2016). FaktorFaktor Yang Mempengaruhi Kethanan Pangan Rumah Tangga Miskin di Wilayah Perkotaan Kabupaten Banyumas. Agrin, 20(2), 169-178. https://doi.org/1410-0029

Omotesho M.O. Adewumi, K. S. F. (2010). Food Security and Poverty of the Rural Households in Kwara State, Nigeria. Libyan Agriculture Research Center Journal International, 1(1), 56-59.

Putri, K., Murniati, K., \& Adawiyah, R. (2019). Pola Konsumsi Dan Tingkat Ketahanan Pangan Rumah Tangga Petani Ubi Kayu Di Kecamatan Terusan Nunyai Kabupaten Lampung Tengah. Online Fakultas Pertanian Unila, 7(3), 391-396. Retrieved from http://jurnal.fp.unila.ac.id/index.php/JI A/article/view/3778

Sianipar, J. E., Hartono, S., \& Hutapea, R. T. P. (2012). Di Kabupaten Manokwari. Analisis Ketahanan Pangan Rumah Tangga Tani Di Kabupaten Manokwari, 8(2), 68-74.

Sugiarto, Ugih; Karyani, Tuti; Rochdiani, D. (2018). Faktor-faktor yang mempengaruhi pangsa pengeluaran pangan rumah tangga petani padi-sapi di kecamatan pangkalan kabupaten karawang. Agribisnis Dan Sosial Ekonomi Pertanian UNPAD, 3(2528).

Sumardilah, D. S., \& Rahmadi, A. (2015). Faktor-faktor yang berhubungan dengan ketahanan pangan rumah tangga. Jurnal Keperawatan, 11(2), 270278.

Suryana, A., Rachman, B., \& Hartono, D. (2014). KETAHANAN PANGAN NASIONAL Dynamics of Rice Price Policy in Support of National Food Security. Pengembangan Inovasi Pertanian, 7, 155-168.

Susanti, E., Fauzi, T., \& Taufiqurrahman. (2015). Analisis Ketahanan Pangan Rumah Tangga Petani di Desa Ulee Lhat Kecamatan Montasik Kabupaten Aceh Besar. Bisnis Tani, 1(1), 11-23. 